\title{
Can selection for resistance to OsHV-1 infection modify susceptibility to Vibrio aestuarianus infection in Crassostrea gigas? First insights from experimental challenges using primary and successive exposures
}

\author{
Patrick Azéma ${ }^{1 *}$, Marie-Agnès Travers ${ }^{1}$, Julien De Lorgeril ${ }^{2}$, Delphine Tourbiez ${ }^{1}$ and Lionel Dégremont ${ }^{1}$
}

\begin{abstract}
Since 2008, the emergent virus OsHV-1 $\mu$ var has provoked massive mortality events in Crassostrea gigas spat and juveniles in France. Since 2012, mortality driven by the pathogenic bacteria Vibrio aestuarianus has stricken market-sized adults. A hypothesis to explain the sudden increase in mortality observed in France since 2012 is that selective pressure due to recurrent viral infections could have led to a higher susceptibility of adults to Vibrio infection. In our study, two OsHV-1-resistant lines (AS and BS) and their respective controls ( $A C$ and $B C$ ) were experimentally challenged in the laboratory to determine their level of susceptibility to $V$. aestuarianus infection. At the juvenile stage, the selected lines exhibited lower mortality (14 and 33\%) than the control lines (71 and 80\%), suggesting dual-resistance to OsHV-1 and $V$. aestuarianus in C. gigas. Interestingly, this pattern was not observed at the adult stage, where higher mortality was detected for AS (68\%) and BC (62\%) than AC (39\%) and BS (49\%). These results were confirmed by the analysis of the expression of 31 immune-related genes in unchallenged oysters. Differential gene expression discriminated oysters according to their susceptibility to infection at both the juvenile and adult stages, suggesting that resistance to $V$. aestuarianus infection resulted in complex interactions between the genotype, stage of development and immunity status. Finally, survivors of the $V$. aestuarianus challenge at the juvenile stage still exhibited significant mortality at the adult stage during a second and third $V$. aestuarianus challenge, indicating that these survivors were not genetically resistant.
\end{abstract}

\section{Introduction}

The French oyster industry has regularly suffered from massive mortality episodes (Figure 1). In the early 1970s, the production of the Portuguese oyster Crassostrea angulata collapsed due to massive mortality related to an iridovirus [1], and the production of the flat oyster Ostrea edulis was significantly reduced due to two parasites (Martelia refringens and Bonamia ostreae) [2]. Once a disease affecting an oyster species has been introduced

\footnotetext{
*Correspondence: pazema@ifremer.fr

1 Ifremer, Laboratoire de Génétique et Pathologie des Mollusques Marins,

Avenue Mus de Loup, 17390 La Tremblade, France

Full list of author information is available at the end of the article
}

or detected in an area, resources to minimize its effect on oyster populations or production are very constrained. Neither large-scale drug use nor vaccination (because invertebrates have no acquired immunity) is possible in open marine areas due to the scale of the environment, and seawater or other organisms can easily convey pathogens from the reservoir to naïve stocks, thereby favoring the transmission of a disease. In this context, two main solutions have been proposed to sustain French oyster production: (1) develop a selective breeding program to enhance disease resistance using the genetic resources available in oyster populations, and more radically (2) introduce another species that is not sensitive to the disease. This second step was taken in France during the 


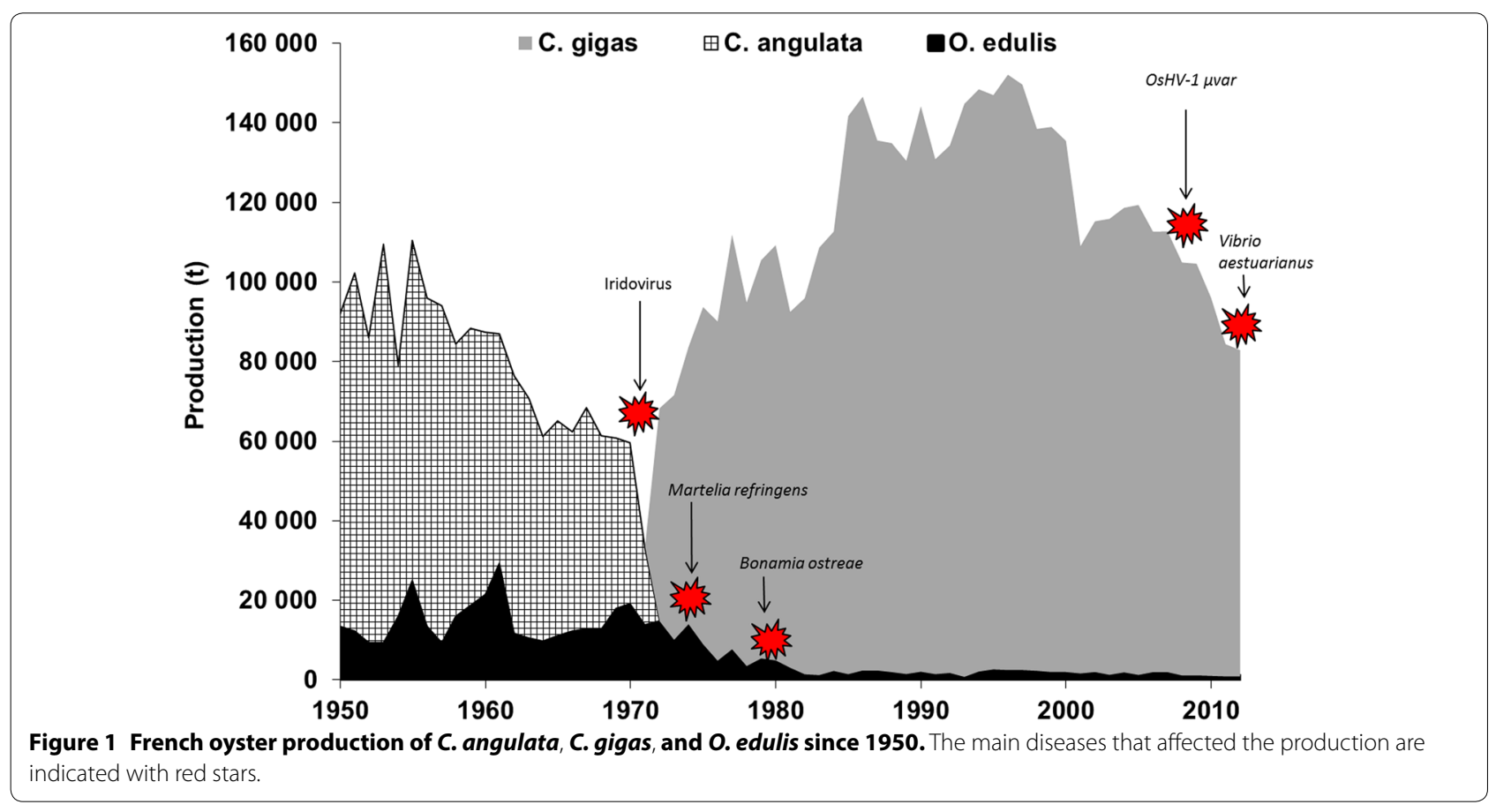

1970s with the massive introduction of Crassostrea gigas from Japan and British Columbia to replace C. angulata during the RESOR operation (Figure 1) [3]. However, the introduction of new species is not recommended because it can lead to the introduction of new diseases in local populations [4], competition for habitats and resources, new invasive species and other constraints (regulatory rules, preliminary studies and biological barriers).

French oyster production of $C$. gigas has ranged from 100000 to 150000 tons for several decades, but has unfortunately begun to decrease due to two diseases (Figure 1). Indeed, massive mortality events have occurred every year since 2008, with high mortality rates for spat and juveniles (over 70\%). A particular OsHV-1 genotype ( $\mu$ var) that was first described during a period of C. gigas mortality in 2004-2005 in Normandy [5] has been ascribed to the mortality [6]. Moreover, significant mortality has been observed in market-sized adults since 2012 [7-9], and C. gigas production is expected to decrease again (Figure 1). The main pathogenic agent found in the dying oysters harvested during these mortality episodes belonged to the species Vibrio aestuarianus. Because it would not be reasonable to introduce another oyster species to replace $C$. gigas, the possibility of genetic selection for disease resistance might limit the impact of diseases on wild and cultivated oysters.

High mortality rates related to OsHV-1 $1 \mu$ var have been observed in the field since 2008 [10], and it is probable that viral pressure on wild and cultivated oyster populations has been significant. Therefore, the emergence of high mortality in adults has made it legitimate to investigate whether the selection provoked by viral infection has an impact on the susceptibility of adults to bacterial infections and whether there are correlations or trade-offs between resistance to OsHV-1 and the expected resistance to $V$. aestuarianus. Consequently, it would be interesting to study whether the mass selection breeding program for $C$. gigas currently being managed at Ifremer [11] could enhance disease resistance to both OsHV-1 and $V$. aestuarianus.

Evidence of OsHV-1 resistance was demonstrated in spat C. gigas in 2009 using oysters selected based on their higher resistance to the summer mortality phenomenon in 2001 [12-14]. More recently, OsHV-1 resistance was found to be a highly heritable trait in C. gigas spat under field and laboratory conditions $[11,15]$. However, experimental selective breeding programs focused on $V$. aestuarianus resistance have not been described to date, and a relationship between resistance to OsHV-1 infection and $V$. aestuarianus infection has not been reported.

One hypothesis to explain disease resistance could be linked to host defenses, such as the immune capacity. Previous works identified markers for oyster survival capacity [16-19]. These studies led to the identification of a set of genes whose expression was either up-regulated in oysters able to survive virulent Vibrio infection [16, $20]$ or differentially regulated in the hemocytes of oysters with a high capacity for survival [18]. 
The objective of this study was to investigate: (1) the resistance to $V$. aestuarianus infection in $C$. gigas at the juvenile and adult stages under laboratory-controlled conditions using two stocks of oysters and (2) to analyze the association of the survival capacity with the basal expression levels of a selection of immune-related genes. For each stock, a control line and a line selected for higher survival at the spat stage under field conditions (which was also related to higher resistance to OsHV-1 infection) were evaluated. First, experimental OsHV-1 infection was performed to confirm the level of resistance of each line to the viral infection. Then, two approaches were used to test for resistance to $V$. aestuarianus infection. The first approach challenged the oysters in primary exposures at the juvenile stage or the adult stage to determine the level of resistance according to the size and/ or age of the oysters. The second approach used successive infections at the adult stage with the survivors of the previous experimental infections to determine whether the survivors became resistant to the bacterial infection. Finally, we evaluated the immune status of non-stimulated oysters before the onset of bacterial infection under laboratory conditions.

\section{Materials and methods Oysters}

A mass selection to increase survival in C. gigas was performed in two stocks (named A and B) of wild oysters sampled from two sites in the Marennes-Oléron Bay (Charente Maritime, France) in 2008. For each line, a base population $G_{0}$ was produced in 2009, and a subsample was kept in our facilities to avoid disease-related mortality and to produce the control line of the following generation $\left(G_{1}-C\right)$. This control allowed the assessment of the effects of changing environmental conditions during the course of the experiment to estimate the response to selection [11]. The other sub-sample of oysters was deployed in the field, where mortality outbreaks caused by OsHV-1 were routinely observed each year since 2009 [21]. Then, the survivors were spawned in 2010 to produce the selected line $G_{1}-S$. The same approach was used in February 2011 and March 2012 to produce $G_{2}$ and $G_{3}$, respectively. Four sub-lines were produced for the selected line from $G_{2}$; further details are given in [11].

The oysters used in this study were the control lines $A C$ and $B C$ of $G_{3}$ and the selected lines AS and BS, which were the best sub-lines for survival and OsHV-1 resistance in the field. The field evaluation of the $C$ and $S$ lines at the spat stage during the summer of 2012 confirmed a higher mortality for the $\mathrm{C}$ lines $(92.9 \%)$ compared with the $\mathrm{S}$ lines (32.0\%). Nevertheless, the oysters used in our experimental infections were either kept in our inland facilities to avoid disease-related mortality or deployed to the field in October 2012 prior to their evaluation in the laboratory (Figure 2).

\section{Viral and bacterial suspensions}

The viral suspension was obtained using the protocol of Schikorski [22]. Briefly, naïve and unselected hatcheryproduced oysters were infected by injecting $50 \mu \mathrm{L}$ of a previous viral suspension after "anesthesia". Dead oysters were dissected; the mantle and gills were removed, pooled, diluted, crushed and filtered using a $0.22-\mu \mathrm{m}$ filter to obtain a clarified tissue homogenate.

The Vibrio strain used in the bacterial challenges was the highly pathogenic strain 02/041 that was isolated during a mortality episode in adults. This strain was previously studied and was included in this study as a reference strain [23]. The Vibrio suspension was obtained from an isolate maintained at $-80{ }^{\circ} \mathrm{C}$. The bacterial strain was placed in liquid Zobell and incubated for $24 \mathrm{~h}$ at $20{ }^{\circ} \mathrm{C}$ with constant shaking at $20 \mathrm{rpm}$. The resulting solution was centrifuged at $3200 \times g$ for $10 \mathrm{~min}$. The supernatant was discarded, and the pellet was washed and suspended in sterile artificial sea water (SASW).

\section{Mortality induction protocols}

Two types of experimental infection protocols were used to evaluate disease resistance in $C$. gigas: a by-injection protocol and a by-cohabitation protocol. For all trials, the seawater was filtered, UV treated and maintained at $21^{\circ} \mathrm{C}$ with adequate aeration and without the addition of food. For the large volume tanks $(150 \mathrm{~L})$, a recirculating system was used to optimize the horizontal transmission of the disease. The salinity ranged between 29.5 and $36.7 \%$ for all trials.

For the by-injection protocol, pathogenic agents were directly injected into the adductor muscles of oysters to test their disease resistance. First, oysters were "anesthetized" in a solution containing magnesium chloride $\left(\mathrm{MgCl}_{2}, 50 \mathrm{~g} / \mathrm{L}\right)$ in a mixture of seawater and distilled water $(1: 4, \mathrm{v}: \mathrm{v})$ for $4 \mathrm{~h}$. Subsequently, $50 \mu \mathrm{L}$ of the infectious solution (bacterial or viral suspension) was injected into the adductor muscle using a $1 \mathrm{~mL}$ micro-syringe equipped with an $18 \mathrm{~g}$ needle. The injected oysters were either naïve oysters of the selected or control lines or naïve unselected hatchery-produced oysters that were used as "sources" for the horizontal transmission of the disease to the selected and control lines through a bycohabitation protocol.

For the by-cohabitation components, we used the protocols previously described in [24, 25]. As described for the by-injection protocol, naïve and unselected hatchery-produced oysters were injected with a specific pathogen and then transferred into tanks for $24 \mathrm{~h}$. Then, they were placed in contact with the naïve 


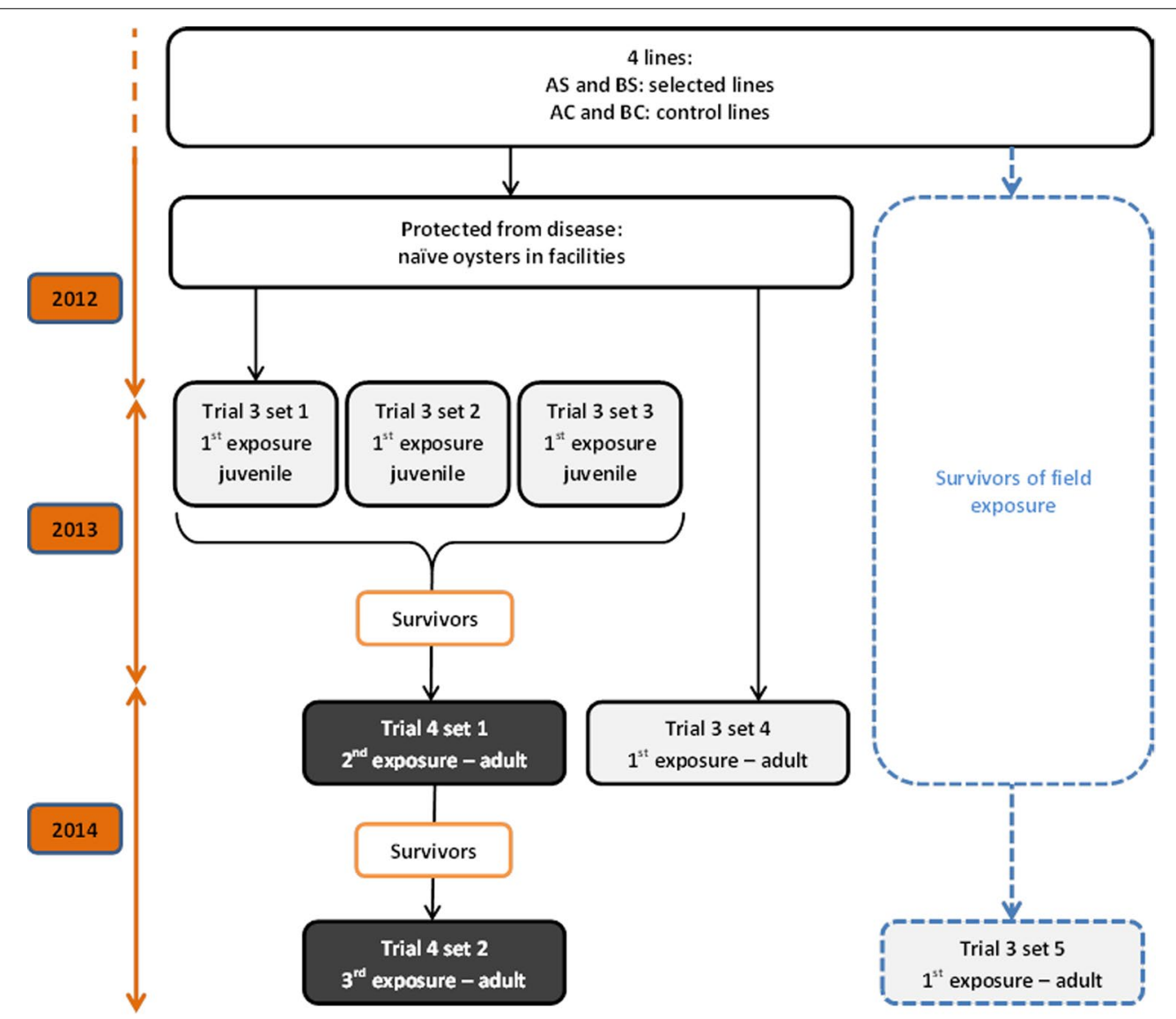

Figure 2 Summary of the production and exposure to $\boldsymbol{V}$. aestuarianus by cohabitation challenges. Trials 3 and 4 were performed for the control and selected lines at either the juvenile or adult stages. Light grey boxes indicate primary-challenge and dark grey boxes indicate a second and third exposure to the bacteria.

oysters of the selected and control lines to test their disease resistance. A ratio of $10 \mathrm{~g}$ of injected oysters (with the shell) per $10 \mathrm{~L}$ of sea water was used for all of the experiments. A dead oyster was defined as a moribund animal that was unable to close its valve after 5 min out of the water.

Trial 1: experimental infection by cohabitation between oysters injected with OsHV-1 and the selected and control lines

An experimental infection with OsHV-1 was performed in April 2013 to verify the higher resistance to OsHV-1 infection of the selected lines AS and BS compared with the control lines $\mathrm{AC}$ and $\mathrm{BC}$. The oysters were 13 months old, and the mean individual weight was $22 \mathrm{~g}$ (Table 1). The AS, BS, AC and BC lines were evaluated throughout the cohabitation with oysters injected with a viral suspension as described above. For each line (AS, BS, AC and $\mathrm{BC}$ ), four $5 \mathrm{~L}$ replicate tanks were used; each tank contained 10 oysters (Table 1 ). For three replicates, 4 oysters injected with the viral suspension were added to each tank for $48 \mathrm{~h}$. In the fourth tank, 4 oysters injected with SASW were added for $48 \mathrm{~h}$. The mortality was recorded daily for 11 days.

\section{Trial 2: experimental infection by injection of the selected} and control lines with V. aestuarianus

The design of this trial consisted of intramuscular injection of the oysters with suspensions with different bacterial concentrations. The bacterial concentration was evaluated spectrometrically at $600 \mathrm{~nm}$ and adjusted to an optical density $(\mathrm{OD})=1$; then, the suspension was serially diluted to obtain theoretical ODs of 0.0002, 0.002, 0.02 and 0.2 , corresponding to $10^{4}, 10^{5}, 10^{6}$ and $10^{7}$ bacteria per $\mathrm{mL}$, respectively. The bacterial concentration and purity were verified by plating. Three $5 \mathrm{~L}$ tanks were used for each OD and each line; each tank contained ten oysters injected with $50 \mu \mathrm{L}$ of $V$. aestuarianus (500 CFU at OD $10^{4}$ and 0.5 million CFU at OD $10^{7}$ ). For each line, an additional tank was used as a control; this tank contained 10 oysters injected with SASW. Observations for mortality were performed daily for 6 days. 
Table 1 Summary of the trials and sets to evaluate OsHV-1 and V. aestuarianus susceptibility.

\begin{tabular}{|c|c|c|c|c|c|c|c|c|c|}
\hline Trial & 1 & 2 & 3 & 3 & 3 & 3 & 3 & 4 & 4 \\
\hline Set & & & 1 & 2 & 3 & 4 & $5^{a}$ & $1^{b}$ & $2^{c}$ \\
\hline Pathogen & OsHV-1 & $\begin{array}{c}\text { Vibrio aestu- } \\
\text { arianus }\end{array}$ & $\begin{array}{c}\text { Vibrio aestu- } \\
\text { arianus }\end{array}$ & $\begin{array}{c}\text { Vibrio aestu- } \\
\text { arianus }\end{array}$ & $\begin{array}{c}\text { Vibrio aestu- } \\
\text { arianus }\end{array}$ & $\begin{array}{l}\text { Vibrio aestu- } \\
\text { arianus }\end{array}$ & $\begin{array}{c}\text { Vibrio aestu- } \\
\text { arianus }\end{array}$ & $\begin{array}{c}\text { Vibrio aestu- } \\
\text { arianus }\end{array}$ & $\begin{array}{l}\text { Vibrio aestu- } \\
\text { arianus }\end{array}$ \\
\hline $\begin{array}{l}\text { Infection } \\
\text { protocol }\end{array}$ & Cohabitation & Injection & Cohabitation & Cohabitation & Cohabitation & Cohabitation & Cohabitation & Cohabitation & Cohabitation \\
\hline $\begin{array}{l}\text { Number of } \\
\text { exposure }\end{array}$ & 1st infection & 1st infection & 1st infection & 1st infection & 1st infection & 1st infection & 1st infection & 2nd infection & 3rd infection \\
\hline $\begin{array}{l}\text { Date of chal- } \\
\text { lenge }\end{array}$ & Apr 2013 & Jan 2013 & Feb 2013 & Mar 2013 & Mar 2013 & May 2014 & Nov 2014 & May 2014 & Nov 2014 \\
\hline $\begin{array}{l}\text { Age } \\
\text { (months) }\end{array}$ & 13 & 10 & 11 & 12 & 13 & 26 & 32 & 26 & 32 \\
\hline $\begin{array}{l}\text { Individual } \\
\text { weight (g) }\end{array}$ & 22 & 22 & 22 & 22 & 22 & 120 & 100 & 100 & 170 \\
\hline Stage & Juvenile & Juvenile & Juvenile & Juvenile & Juvenile & Adult & Adult & Adult & Adult \\
\hline $\begin{array}{c}\text { Number of } \\
\operatorname{tanks}^{\mathrm{f}}\end{array}$ & 12 & 48 & 3 & 3 & 8 & 2 & 2 & 1 & 1 \\
\hline $\begin{array}{l}\text { Tank volume } \\
(\mathrm{L})\end{array}$ & 5 & 5 & 150 & 150 & 10 & 150 & 150 & 150 & 150 \\
\hline Lines tank $^{-1}$ & 1 & 1 & 4 & 4 & 1 & 4 & 4 & 4 & $3^{d}$ \\
\hline $\begin{array}{l}\text { Oysters line-1 } \\
\operatorname{tank}^{-1}\end{array}$ & 10 & 10 & 25 & 25 & $15-20$ & $24-32$ & $28-33$ & $1-88^{e}$ & $1-30^{e}$ \\
\hline $\begin{array}{l}\text { OsHV-1 } \\
\text { detection } \\
\text { in mori- } \\
\text { bunds }\end{array}$ & Yes & No & No & No & No & No & No & No & No \\
\hline $\begin{array}{l}\text { V. aestuari- } \\
\text { anus detec- } \\
\text { tion in } \\
\text { moribunds }\end{array}$ & No & Yes & Yes & Yes & Yes & Yes & Yes & Yes & Yes \\
\hline
\end{tabular}

For all trials, two unselected and control lines (AC and BC) and two lines selected for their higher resistance to OsHV-1 (AS and BS) were evaluated under controlled conditions

a Oysters used were survivors from field testing

b Oysters used were survivors from sets 1 to 3 of trial 3

c Oysters used were survivors from set 1 of trial 4

$d$ One of the control line had 100\% mortality before the trial

e Selected lines had at least 28 and 12 oysters in sets 4 and 5, respectively, whereas the control lines had less than 5 oysters

$\mathrm{f}$ The number indicated is without the control tanks

Trial 3: primary infection by cohabitation between oysters injected with V. aestuarianus and the selected and control lines

Five sets of trials using a by-cohabitation protocol were used to better mimic natural infection. For each trial (with the exception of set 3), three $150 \mathrm{~L}$ tanks were used to challenge a larger number of larger animals at the same time. An additional tank was used for the controls, which consisted of oysters intramuscularly injected with SASW and placed as sources in contact with the four lines (Table 1). In each tank, the oysters of the four lines were randomly placed together in the same tank with 25 oysters per line with the shells individually tagged for identification. For set 3 of trial 3, two $10 \mathrm{~L}$ tanks were used per line; each tank contained approximately $15-20$ oysters (Table 1 ).
The five sets of trial used to evaluate the resistance of the four lines $\mathrm{AS}, \mathrm{AC}, \mathrm{BS}$ and $\mathrm{BC}$ to $V$. aestuarianus are summarized in Table 1 and Figure 2:

- Three sets were performed in February and March 2013. The naïve oysters were 11-13 months old and weighed $22 \mathrm{~g}$ (Table 1), which corresponded to the juvenile stage according to the oyster industry. All oysters were always kept in our facilities, and no mortality was recorded.

- The fourth set was conducted during spring 2014. The oysters were 26 months old, and the mean individual weight was $120 \mathrm{~g}$ (Table 1), which corresponded to the adult stage. The oysters were always kept in our facilities, and no mortality was recorded. 
- The fifth set was conducted during the fall of 2014 with oysters kept for 2 years in the field at Agnas (Charente Maritime, France). The control and selected oyster lines experienced 70 and 34\% mortality, respectively. The oysters were 32 months old, and the mean individual weight was $100 \mathrm{~g}$.

Trial 4: successive infections by cohabitation of oysters injected with V. aestuarianus and the selected and control lines

All oysters that survived sets $1-3$ in trial 3 were again challenged in trial 4 with two additional successive challenges in May 2014 and November 2014 (Figure 2). Between trial 3 and the first set in trial 4 and between the two sets of trial 4 , the oysters were kept at the Ifremer facilities in La Tremblade. All effluent from the holding facilities was treated with chlorine. The occurrence of mortality was also recorded during these periods. In set 1 of trial 4, the oysters were 26 months old with an average weight of $100 \mathrm{~g}$, whereas in set 2 of trial 4 the oysters were 32 months old with an average weight of $170 \mathrm{~g}$ (Table 1).

\section{Detection of OsHV-1 and V. aestuarianus DNA}

For all of the trials, moribund oysters from the selected and control lines were sampled for the detection of OsHV-1 and $V$. aestuarianus DNA. Total DNA was extracted from tissue fragments (mantle + gills) using the QIAgen (Hilden, Germany) QIAamp tissue mini kit combined with the QIAcube automated system according to the manufacturer's protocol. The total DNA amount was adjusted to $5 \mathrm{ng} / \mu \mathrm{L}$ following Nanodrop (Thermo Scientific) measurement.

A real-time PCR assay was conducted on the MX3000 and MX3005 Thermocyclers (Agilent) using the Brilliant III Ultrafast kit (Stratagene). Each reaction was run in duplicate in a final volume of $20 \mu \mathrm{L}$ containing the DNA sample ( $5 \mu \mathrm{L}$ at a $5 \mathrm{ng} / \mu \mathrm{L}$ concentration), $200 \mathrm{nM}$ of each primer (for OsHV-1, DPF 5' ATT GAT GATGTG GAT AAT CTG TG $3^{\prime}$ and DPR $5^{\prime}$ GGT AAA TAC CAT TGG TCT TGTTCC $3^{\prime}$ [26] and for $V$. aestuarianus, DNAj-F $5^{\prime}$ GTATGAAATTTTAACTGACCCACAA3 ${ }^{\prime}$ and DNAj$\mathrm{R} 5^{\prime}$ CAATTTCTTTCGAACAACCAC $3^{\prime}$ [27]) and $200 \mathrm{nM}$ of an oligonucleotide probe (for $V$. aestuarianus DNAj, probe $5^{\prime}$ TGGTAGCGCAGACTTCGGCGAC). The real-time PCR cycling conditions were as follows: 3 min at $95{ }^{\circ} \mathrm{C}$, followed by 40 cycles of amplification at $95^{\circ} \mathrm{C}$ for $5 \mathrm{~s}$ and $60^{\circ} \mathrm{C}$ for $20 \mathrm{~s}$. For OsHV-1 DNA quantification, melting curves were also plotted $\left(55-95^{\circ} \mathrm{C}\right)$ to ensure that a single PCR product was amplified for each set of primers. Negative controls (without DNA) were included.

\section{Evaluation of the immune status of the selected and control lines}

The immune statuses of the oyster lines were evaluated based on the expression of immune-related genes in the $\mathrm{AS}, \mathrm{AC}, \mathrm{BS}$ and $\mathrm{BC}$ lines prior to trial 3 set 1 at 12 months and trial 3 set 5 at 32 months. Immunerelated genes were selected based on previous studies showing their transcriptomic regulation following vibrio challenge or between oyster lines selected for their resistance/sensitivity to in situ mortality $[16,18]$. Oysters were removed from their shells, and the whole soft body was immediately plunged into liquid nitrogen. Then, the oysters were pulverized in groups (three groups of 10 oysters per oyster line) with a Mixer Mill MM 400 (Retsch) under liquid nitrogen conditions. The frozen oyster powder was stored at $-80{ }^{\circ} \mathrm{C}$ prior to RNA extraction for gene expression analysis.

RNA extraction from the frozen oyster powder was performed with the TRIzol Reagent (Invitrogen) according to the manufacturer's instructions. Briefly, $100 \mathrm{mg}$ of oyster powder was homogenized in $1 \mathrm{~mL}$ of TRIzol by vortexing for $1 \mathrm{~h}$ at $4{ }^{\circ} \mathrm{C}$. Next, the RNA samples were treated with $5 \mathrm{U}$ of DNase I (Invitrogen) to eliminate DNA contamination according to the manufacturer's instructions, followed by RNA precipitation to eliminate the degraded DNA (with 100\% isopropyl alcohol and $3 \mathrm{M}$ Na-acetate). Then, the RNA samples were dissolved in $50 \mu \mathrm{L}$ of RNase-free water and quantified using a NanoDrop spectrophotometer (Thermo Scientific). The integrity of the total RNA was verified using $1.5 \%$ agarose gel electrophoresis. Finally, total RNA was reverse transcribed using the Moloney Murine Leukemia Virus Reverse Transcriptase (MMLV-RT) according to the manufacturer's instructions (Invitrogen).

qPCR assays were performed on the Light-Cycler 480 System (Roche) in a final volume of $5 \mu \mathrm{L}$ containing $1 \times$ Light-Cycler 480 master mix, $0.5 \mu \mathrm{M}$ of each primer and $1 \mu \mathrm{L}$ of cDNA diluted $1 / 8$ in sterile ultra-pure water. The primer pairs used to amplify the 31 immune-related genes are listed in Table 2. Primer pair efficiencies (E) were calculated by five serial dilutions of pooled cDNA ranging from $1 / 2$ to $1 / 64$ in sterile ultra-pure water using the slopes provided by the LightCycler software according to the equation: $\mathrm{E}=10^{[-1 / \text { slope }]}$. The $\mathrm{qPCR}$ program was composed of an initial denaturation step of $15 \mathrm{~min}$ at $95{ }^{\circ} \mathrm{C}$, followed by amplification of the target cDNA ( 35 cycles of denaturation at $95^{\circ} \mathrm{C}$ for $10 \mathrm{~s}$, annealing at $57^{\circ} \mathrm{C}$ for $20 \mathrm{~s}$ and extension at $72{ }^{\circ} \mathrm{C}$ for $25 \mathrm{~s}$ with fluorescence detection). Relative expression levels of the immunerelated genes were calculated with the method described by Pfaffl [28] and normalized using the mean of values of three constitutively expressed genes $(C g-E F 1$ [GenBank 
Table 2 Primers and functional categories of the analyzed immune-related genes.

\begin{tabular}{|c|c|c|c|c|}
\hline Gene number & Functional category & Name & Sense primer & AntiSense primer \\
\hline 72 & Immune response & Metallothionein a & CAGCTCACACAGTCCCTTC & CATGTACAGTTACACGATGC \\
\hline 122 & Immune response & Universal stress protein & TTGAGGTTTCCGTGAACGAG & AACAATCACCGGAACTGACG \\
\hline 130 & Immune response & Interferon-induced protein 44 & AAGATCCAACGATGAAAGAC & TTGTCGACATCACTACAAAC \\
\hline 163 & Immune response & Big defensin & TTCGCCTGCTTCCATACTGG & GTCATGGTCACTCCTTATTC \\
\hline 189 & Immune response & C-type lectin 2 like protein & GTCATCTGACCACAATTACAG & TCGATAGCAGCATTCCAGAG \\
\hline 220 & Immune response & MyD88 adaptor & AGGTACCGGCTGTGATACGA & TTCAAACGCCACCAAGACTG \\
\hline 234 & Immune response & $\begin{array}{l}\text { Tumor necrosis factor ligand super- } \\
\text { family }\end{array}$ & GGATACGCAAGAGGAACTGC & TGGACATTAACGACACGCGC \\
\hline 293 & Immune response & Interleukin 17 & ACTGAGGCTCGATGCAAGTG & AGCCTTCTTGCTTCATGTGG \\
\hline 300 & Immune response & Heat shock protein 70 & GCATGTGAGCGAGCAAAACG & TGGCAGCTTGAACAGCAGC \\
\hline 303 & Immune response & Galectin & ACGAAACGCTCTGATTGGTG & TTAGTGGCATGGTAGGTCTG \\
\hline 304 & Immune response & L-rhamnose-binding lectin & AGATGATTGTGAAAGCAGCGA & ACTGTAGCGGTCATGCTCTG \\
\hline 306 & Immune response & Proline rich protein & CACCATGTTCTCTCGGAGGA & GTCTGCAATGTTAACCCTCAG \\
\hline 307 & Immune response & Hemocyte defensin & GTTGTAGAGCGGGCTACTGTG & CTTGGTCAGATTCAGACTGG \\
\hline 351 & Immune response & Metallothionein b & GGAACTGTAGCTGTGGAGAC & CCTTCTTACAGCAGCAGTCG \\
\hline 399 & Immune response & Metallothionein c & ATGTCCGATCATTGTTCCTG & ACAGGTTTCTGGTCCGTGAC \\
\hline 8 & Cellular differentiation & Angiopoietin-1 receptor a & TGACGTGCTCGGCAACATGC & CATTGTGTCCCCGTGAAGCC \\
\hline 312 & Cellular differentiation & Angiopoietin-1 receptor b & CGAAATCGTCTTACGAACGC & GTTAGCAAGATCCCGTTGAG \\
\hline 324 & Cellular differentiation & Early growth response protein & CTACCTCCACAAGCGACATG & ACGTCGTTACTATGTGAGGG \\
\hline 216 & Cellular differentiation & Placental protein 11 & GCCAGATTTACCTGGAATGG & ATGCGGTGTAGATAGCGATG \\
\hline 375 & Cellular differentiation & GTP-binding protein Di-Ras2 & TTGGGCGTACAGTGACAACC & TCTCTGTTTCCTCGTGAACC \\
\hline 396 & Cytoskeleton reorganization & Acyl-CoA desaturase & AGATGCAGACCCACACAACG & GCGTTCCAAAGTGATTCTCC \\
\hline 401 & Cytoskeleton reorganization & Neurotrypsin & AAACAATGCAAGGGAGAAGC & CTATTGTCAGCACAATCTGG \\
\hline 441 & Cytoskeleton reorganization & Major vault protein & TTCAAGAGTCAAGTGGATGC & ACCATTGGCGGTATTGAAGG \\
\hline 439 & Cytoskeleton reorganization & Myosin essential light chain & TACATAACGGGTCATGAGAC & CAACACTGGATTACCACCTG \\
\hline 348 & Cytoskeleton reorganization & Calcineurin subunit B isoform 1 & ACGGTGTATTCCTTGTGTCC & TCTTCTGTACATGCAAGTGG \\
\hline 284 & Cell adhesion-communication & Integrin beta-PS & CCCACCTAGTGCCAGTCAAG & GAACTTTGACTTGTGTGACGT \\
\hline 420 & Cell adhesion-communication & $\begin{array}{l}\text { Hemagglutinin/amebocyte aggrega- } \\
\text { tion factor precursor }\end{array}$ & TCGTGAATGCTGAACACACC & TACACCTGTCCAAACCAAGG \\
\hline 283 & Respiratory chain & Extracellular superoxide dismutase & AGAGGTGAATGCTACCAGG & AGGCCAAGAATTCCGTCTG \\
\hline 422 & Respiratory chain & Glutathione transferase omega-1 & TTGGACAGGTTACCACACAG & CAAACCAAGGCCATACCATG \\
\hline 378 & Pro- and anti-apoptosis & Caspase 7 & AGGGAGACAAGCGCCGTCAG & TCCTCATTTGCTCTTCGTTC \\
\hline 166 & No hit & Unknown gene product 166 & AAGTCGTATAGGAGCACAGG & GGCTGAGAACATAATCCTCC \\
\hline
\end{tabular}

AB122066], Cg-RPL4O [GenBank FP004478] and CgRPS6 [GenBank HS119070]).

\section{Statistical analyses}

Survival was analyzed with the SAS 9 software using the GLIMMIX procedure by a logistic regression for binomial data. The general model for the first trial was:

$$
\begin{aligned}
Y_{i}= & \operatorname{Logit}(\pi)=\ln \frac{\pi}{1-\pi}=\mu+\text { stock }_{i} \\
& +\operatorname{selection}_{j}+\text { stock }_{i} * \text { selection }_{j}+\varepsilon
\end{aligned}
$$

where $Y_{i}$ was the survival probability, $\mu$ was the intercept, stock $_{i}$ represented stock A or line B, and selection ${ }_{j}$ represented the level of selection for OsHV-1 resistance (selected or control).
For trial 2, the bacterial concentration factor and all interactions between the bacterial concentrations, the stock and the selection factors were added to the model.

For the first three sets of challenges in trial 3, the set factor and its interactions were added to the model. A similar model was also used for the last two sets of challenges in trial 4.

For the gene expression analysis, statistical analysis was performed using the STATISTICA software version 7.1 (StatSoft) using the Mann-Whitney U test (significant value: $p<0.05$ ). Hierarchical clustering of the gene expression data was performed with the Multiple ArrayViewer software using the average linkage clustering with the Spearman Rank Correlation as the default distance metric. 


\section{Results}

Trial 1: experimental infection by cohabitation between oysters injected with OsHV-1 and the selected and control lines

No mortality occurred in the control tanks for each line (AC, AS, BC and BS). The first mortality occurred on day 2 , and a peak of mortality was observed on day 5 . As expected, the selected oysters presented low mortality (3 and $7 \%$ for AS and BS, respectively), whereas the control oysters had significantly higher mortality (60 and 67\% for $\mathrm{AC}$ and $\mathrm{BC}$, respectively, $p<0.001$ ). The mean mortality was 32 and $37 \%$ for stocks $A$ and B, respectively. The mortality between these stocks was not significantly different. Moreover, no difference was observed for the interaction between the stocks and the level of selection for resistance to OsHV-1 infection $(p>0.05)$. High amounts of OsHV-1 DNA was detected in all of the moribund oyster samples analyzed $(n=31)$.

Trial 2: experimental infection by injection of the selected and control lines with $V$. aestuarianus

No mortality was observed for oysters injected with SASW in the control tanks. The mortality rates of each line at each injected dose are shown in Figure 3. Very high mortality ranging from 77 to $100 \%$ was observed for all lines regardless of the infectious dose. None of the factors were significant with the exception of the bacterial concentration factor $(p=0.0003)$ and the interaction between the stock and level of selection $(p=0.0005)$ (Table 3). At the stock level, the selected line exhibited lower mortality compared to the control line for stock $B$ at each bacterial concentration; the opposite effect was observed for stock A at the two lowest concentrations (Figure 3). The mortality at the lowest bacterial
Table 3 Logit analysis of mortality in Trial 2.

\begin{tabular}{llll}
\hline Effect & DF & F & P \\
\hline Stock & 1 & 2.42 & 0.1207 \\
Selection & 1 & 0.6 & 0.4374 \\
Bacterial concentration & 3 & 6.29 & 0.0003 \\
Stock $\times$ selection & 1 & 12.23 & 0.0005 \\
Stock $\times$ bacterial concentration & 3 & 1.31 & 0.2708 \\
Selection $\times$ bacterial concentration & 3 & 0.5 & 0.6801 \\
Stock $\times$ selection $\times$ bacterial concentration & 3 & 2.06 & 0.1042
\end{tabular}

Oyster lines were challenged at the juvenile stage for primary infection by injection of $V$. aestuarianus for the control and selected lines of both stocks and at different doses

concentration was significantly lower compared to the morality at the other concentrations $(p<0.0001)$.

Trial 3: primary infection by cohabitation between oysters injected with V. aestuarianus and the selected and control lines at the juvenile and adult stages

Primary exposure with the V. aestuarianus cohabitation protocol at the juvenile stage (sets 1 to 3)

No mortality occurred in the control tanks of each set of trial 3. All moribund oysters sampled were positive for $V$. aestuarianus DNA $(n=45)$. The mortality of each line at the endpoint for the first three sets of trial 3 (corresponding to the juvenile stage) is presented in Figure 4. In contrast to the by-injection protocol, higher variability in mortality was observed among the lines, with a range from 6 to $90 \%$. A significant interaction was found between the sets and selection $(p=0.0008)$ (Table 4$)$; this interaction was explained at the selection level, with higher mortality observed in set 1 compared to set 3 for the selected lines and the highest mortality observed in

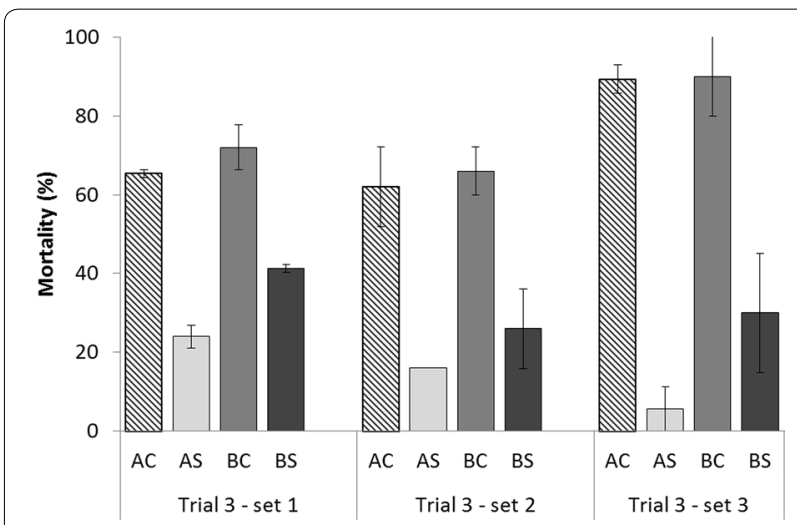

Figure 4 Mean mortality (sd between tanks) in Trial 3 sets 1 to 3. Oyster lines were challenged at the juvenile stage via cohabitation challenges between oysters injected with $V$. aestuarianus and healthy juveniles of the control ( $A C$ and $B C$ ) and selected lines ( $A S$ and $B S$ ). 
Table 4 Logit analysis of mortality in Trial 3 sets 1 to 3.

\begin{tabular}{llrl}
\hline Effect & DF & F & P \\
\hline Set & 2 & 2.41 & 0.0909 \\
Stock & 1 & 7.46 & 0.0065 \\
Selection & 1 & 107.19 & $<.0001$ \\
Set $\times$ stock & 2 & 0.43 & 0.6518 \\
Set $\times$ selection & 2 & 7.25 & 0.0008 \\
Stock $\times$ selection & 1 & 3.81 & 0.0515 \\
Set $\times$ stock $\times$ selection & 2 & 0.64 & 0.8576
\end{tabular}

Oyster lines were challenged at the juvenile stage for a primary infection throughout 3 sets of cohabitation between oysters injected with V. aestuarianus and the control and selected lines of both stocks

the control lines in set 3 (Figure 4). The mean mortalities of the three sets were 14 and $33 \%$ for the AS and BS lines, respectively; this mortality was significantly lower than the mortality observed for the control lines (71 and $80 \%$ for AC and BC, respectively, $p<0.0001$ ) (Table 4). To a much lesser extent, stock A had significantly lower mortality (43\%) than stock B $(53 \%)(p=0.0065)$.

\section{Primary exposure with the $V$. aestuarianus cohabitation protocol at the adult stage (sets 4 and 5 )}

For the fourth set of trial 3, the mortality was 87, 45, 62 and $70 \%$ for the $\mathrm{AS}, \mathrm{AC}, \mathrm{BS}$ and $\mathrm{BC}$ lines, respectively; the mortality decreased to $49,32,36$ and $53 \%$, respectively, in the fifth set of challenges in trial 3 (Figure 5). None of the factors were significant with the exception of a significantly lower mortality in the fifth set compared to the fourth set $(p=0.0002)$ and a significant interaction between the stocks and level of selection $(p=0.0012)$ (Table 5). At the stock level, the stock A control line

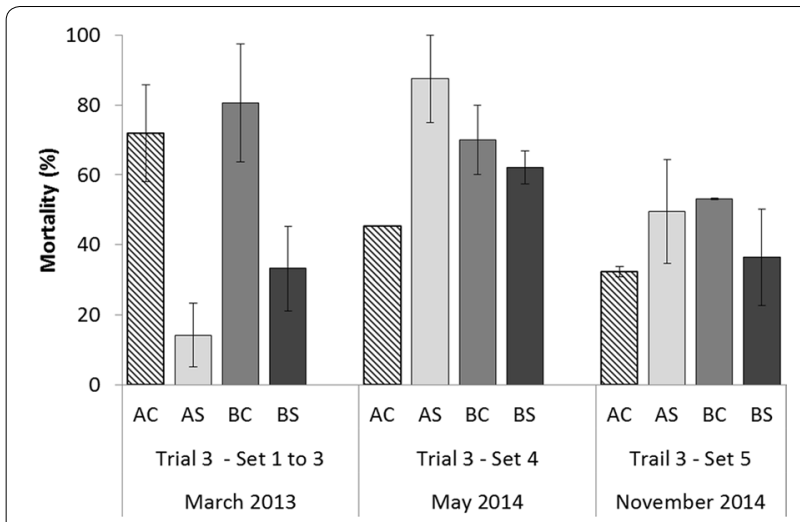

Figure 5 Mean mortality (sd within I) in Trial 3 sets 4 and 5. Oyster lines were challenged at the juvenile stage for the three first sets of trial 3 and at the adult stage for sets 4 and 5 of trial 3 via cohabitation challenges between oysters injected with $V$. aestuarianus and healthy juveniles of the control (AC and $B C$ ) and selected lines (AS and BS).
Table 5 Logit analysis of mortality in Trial 3 set 4 and 5.

\begin{tabular}{llrl}
\hline Effect & DF & F & P \\
\hline Set & 1 & 13.85 & 0.0002 \\
Stock & 1 & 0.00 & 0.9557 \\
Selection & 1 & 2.23 & 0.1368 \\
Set $\times$ stock & 1 & 0.40 & 0.5278 \\
Set $\times$ selection & 1 & 2.39 & 0.1233 \\
Stock $\times$ selection & 1 & 10.72 & 0.0012 \\
Set $\times$ stock $\times$ selection & 1 & 0.82 & 0.3648
\end{tabular}

Oyster lines were challenged at the adult stage for a primary infection throughout 2 sets of cohabitations between oysters injected with $V$. aestuarianus and the control and selected lines of both stocks

had significantly lower mortality than the selected line, whereas the opposite trend was observed for stock B (Figure 5).

\section{Expression levels of immune-related genes can} discriminate oyster lines in terms of susceptibility/ resistance to $V$. aestuarianus infection at the juvenile and adult stages

The hierarchical clustering of the 31 immune-related genes or only the differentially expressed genes $(p<0.05)$ could separate the oyster lines in terms of their resistance/sensitivity to bacterial infection at the two developmental stages analyzed (12 and 32 months, Figure 6). At 12 months of age, hierarchical clustering of the gene expression data separated the oyster lines into two major clusters of conditions: the first cluster included the AS and BS lines, while the second cluster included the $\mathrm{AC}$ and $\mathrm{BC}$ lines (Figure 6A). At 32 months of age, two major clusters of conditions were found that were similar to those observed for the 12 month old oysters, but the oyster lines did not separate in the same manner (Figure 6B): the first cluster included the $\mathrm{AC}$ and BS lines, whereas the second cluster included the $\mathrm{AS}$ and $\mathrm{BC}$ lines. Interestingly, these discriminations of the oyster lines were in accordance with the resistance/ sensitivity to infection of the lines at 12 and 32 months of age.

In the juveniles, 11 genes showed differential gene expression patterns, while in the adults only 7 genes showed differential expression patterns. Among these differentially expressed genes, four genes were common to juveniles and adults (306, 283, 284 and 304). These four genes showed the same patterns of expression in the juveniles and adults according to their resistance/sensitivity to infection. Thus, genes expressed at higher levels in the susceptible lines ( $\mathrm{AC}$ and $\mathrm{BC}$ ) vs. the resistant lines (AS and BS) in juveniles also appeared to be expressed at higher levels in the susceptible lines (AC and BS) vs. 


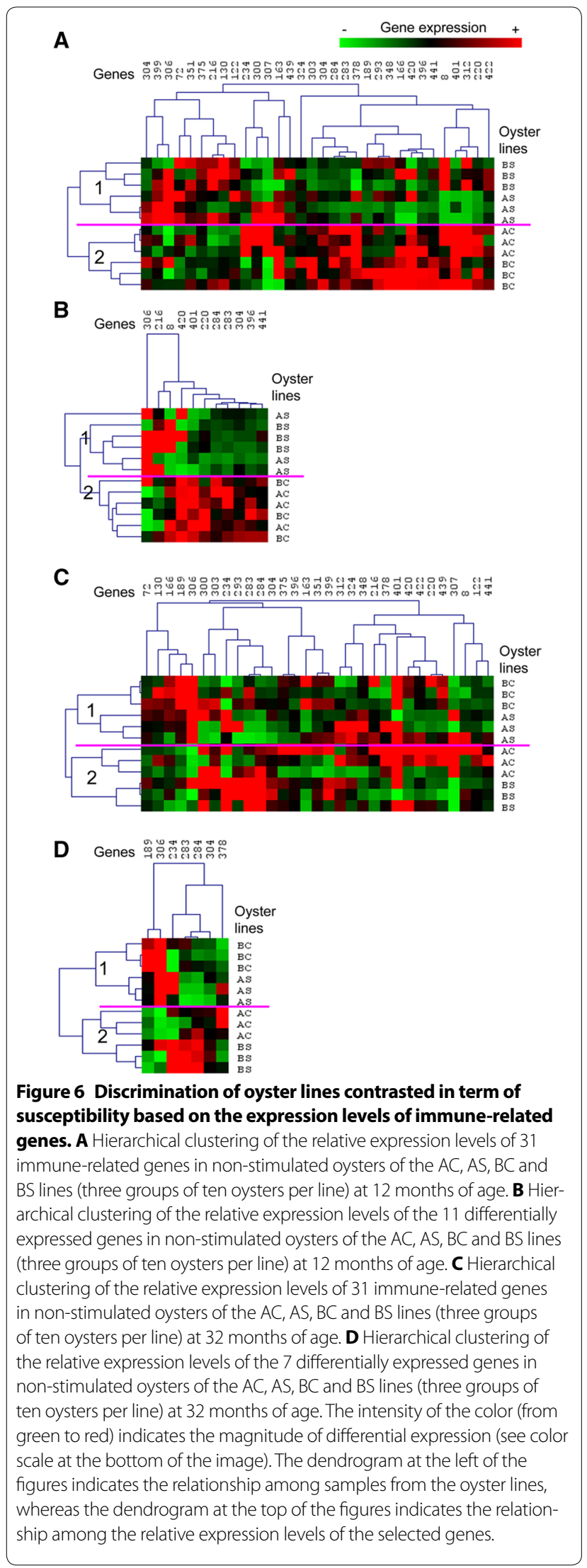

the resistant lines (AS and BC) in adults (genes 283, 284 and 304). Likewise, the gene expressed at a higher level in the resistant lines (AS and BS) vs. the susceptible lines ( $\mathrm{AC}$ and $\mathrm{BC}$ ) in juveniles also appeared to be expressed at a higher level in the resistant lines (AS and $\mathrm{BC}$ ) vs. the susceptible lines (AC and BS) in adults (gene 306). Other differentially expressed genes appeared to be associated with one developmental stage: 7 genes were found to be differentially expressed only in juveniles $(216,8,420,401$, 220, 396 and 441), and 3 genes were found to be differentially expressed only in adults (189, 234 and 378$)$.

\section{Trial 4: successive infections by cohabitation}

\section{between oysters injected with V. aestuarianus and the} selected and control lines

After the three first sets of bacterial challenges of trial 3, the final mortality was $14,71,33$ and $80 \%$ for AS, AC, BS and $\mathrm{BC}$, respectively. During the period between trials 3 and 4, the survivors were kept in a tank with filtered and UV-treated seawater enriched with microalgae. Although this period did not represent a disease challenge, the survivors still experienced significant mortality associated with the detection of $V$. aestuarianus DNA in the moribund oysters. Most of the mortality was observed in July 2013 after a spawning event. The mortality between trial 3 and the first set of challenges of trial 4 was 74, 90, 32 and $97 \%$ for AS, AC, BS and BC, respectively (Table 6); consequently, the cumulative mortality due to $V$. aestuarianus before trial 4 reached $78,96,54$ and $99 \%$, respectively. Although the control lines were tested in trial 4, the remaining oysters numbered less than 5 . Therefore, the mortality was not compared with the selected lines. During the first set of challenges in trial 4, the mortality was 46 and $28 \%$ for AS and BS, respectively (Table 5). No significant difference in mortality $(<5 \%)$ was reported between the two sets of challenges in trial 4. Finally, the survivors exhibited some mortality, with 60 and 38\% mortality for AS and BS, respectively (Table 6). The cumulative mortality after three successive challenges with $V$. aestuarianus in trials 3 and 4 (including the mortality between trials) was $96,99,84$ and $100 \%$ for AS, AC, $\mathrm{BS}$ and $\mathrm{BC}$, respectively (Table 6).

\section{Discussion}

While mortality related to OsHV-1 and $V$. aestuarianus was reported in C. gigas in France prior to 2008 [27, 29], their impact on French oyster production became predominant due to recurrent and intense mortality in spat and adult oysters. While selective breeding to enhance resistance to OsHV-1 infection in C. gigas has been recently demonstrated $[11,15]$, this demonstration is under investigation for $V$. aestuarianus. Nevertheless, this study aimed to elucidate whether selective pressure 
Table 6 Mortality rates per line during three successive challenges.

\begin{tabular}{|c|c|c|c|c|}
\hline & AS & $A C$ & BS & BC \\
\hline Initial number of oysters & 160 & 153 & 165 & 155 \\
\hline $\begin{array}{l}\text { Mean mortality of sets } 1 \text { to } 3 \text { of trial } 3 \text { (Feb to } \\
\text { Mar 2013) (\%) }\end{array}$ & 14 & 71 & 33 & 80 \\
\hline $\begin{array}{l}\text { Mortality between trial } 3 \text { and the first set of } \\
\text { trial } 4(\%)\end{array}$ & 74 & 90 & 32 & 97 \\
\hline First set of trial 4 in Mar 2014 (\%) & 46 & 40 & 28 & 100 \\
\hline Mortality between the two sets of trial $4(\%)$ & $<5$ & $<5$ & $<5$ & - \\
\hline Second set of trial 4 in Nov 2014 (\%) & 60 & 0 & 38 & - \\
\hline $\begin{array}{l}\text { Final oysters number remaining after three suc- } \\
\text { cessive challenges }\end{array}$ & -6 & 1 & 26 & 0 \\
\hline $\begin{array}{l}\text { Cumulated mortality after three successive } \\
\text { challenges (\%) }\end{array}$ & 96 & 99 & 84 & 100 \\
\hline
\end{tabular}

Cumulative mortality by cohabitation between oysters injected with $V$. aestuarianus and the control ( $\mathrm{AC}$ and $\mathrm{BC}$ ) and selected lines (AS and $\mathrm{BS}$ ) are shown from sets 1,2 , and 3 of trial 3 and sets 1 and 2 of trial 4

In italics, the number of oysters was less than 5

exerted by viral infections in the field could impact the susceptibility of $C$. gigas to bacterial infection.

In trial 1 , the selected lines of both stocks exhibited much lower mortality (AS 3\% and BS 7\%) than the control lines (AC 60\% and BC 67\%). Although higher mortality was observed in the field evaluation (50 and 35\% for AS and BS, respectively, and 91 and $94 \%$ for $\mathrm{AC}$ and $\mathrm{BC}$, respectively [11]), our result was consistent with the field evaluation and supported that selection to enhance survival in C. gigas spat was effective for herpes virus infection. The lower mortality observed in our study could be explained by the use of larger ( $20 \mathrm{~g}$ versus $<7 \mathrm{~g}$ ) and older (13 months old versus $<5$ months old) oysters (juvenile versus spat) because OsHV-1 resistance increased with age and size [21]. However, the most important information from trial 1 was the confirmation that AS and BS had higher resistance to OsHV-1 infection than AC and BC before their evaluation of exposure to $V$. aestuarianus.

In trial 2, the mortality of three of the lines reached $100 \%$. The mortality for BS was $>90 \%$ at higher bacterial concentrations corresponding to $5 \times 10^{4}$ and $5 \times 10^{5}$ CFU per oyster (Figure 3). Although the mortality was slightly lower at the lowest bacterial concentration (corresponding to $500 \mathrm{CFU}$ per oyster and ranging from 76 to 96\%; Figure 3), this finding confirmed that strain $02 / 041$ was a highly virulent strain in C. gigas juveniles $(20 \mathrm{~g})$; this finding was recently demonstrated in spat weighing $1.5 \mathrm{~g}$ that exhibited high mortality $(>75 \%)$ at doses of $10^{2}$ and $10^{7} \mathrm{CFU}$ per spat [30]. Consequently, selective breeding to enhance higher resistance to OsHV-1 at the spat stage but does not confer higher resistance to $V$. aestuarianus infection at the juvenile stage. Injection of the bacteria directly into the adductor muscle may bypass the oysters' natural barriers to infection by $V$. aestuarianus. Due to the high mortality observed for all lines when the injection method is used, the cohabitation method should be applied to evaluate the resistance to V. aestuarianus infection of the control and the selected lines because transmission of the bacteria between oysters is what is expected to occur under natural conditions.

The three sets of trial 3 were performed at the juvenile stage, and all exhibited the same mortality patterns. The main finding revealed that the selected lines AS and BS had lower mortality than the control lines AC and BC (Figure 4). This result suggested that selection to increase survival at the spat stage in the field was also efficient in enhancing dual resistance to OsHV-1 infection and $V$. aestuarianus infection at the juvenile stage. A similar result was observed in Crassostrea virginica for dual resistance to Haplosporidium nelsoni and Perkinsus marinus [31], but most studies revealed that breeding for higher resistance to a disease did not confer a higher resistance to another disease [32].

Controversially, this pattern was not found at the adult stage, where much higher mortality was observed for both of the selected lines (particularly the AS line). Indeed, line AS exhibited $87 \%$ mortality in set 4 of trial 3 , whereas the control line AC had lower mortality (45\%) (Figure 5). Additionally, while the AS line had higher mortality in adults than in juveniles, the AC line had lower mortality at the adult stage (45\%) than at the spat stage (71\%) (Figure 5). This same pattern was observed for BS and BC to a lesser extent, except that BS had lower mortality than BC at the adult stage (Figure 5). A similar pattern was observed in set 5 of trial 3 , although the mortality was lower than the mortality recorded in set 4 of trial 3. For set 5 of trial 3, it is important to note that the oysters were survivors of field mortality events that could have been related to OsHV-1 and/or $V$. aestuarianus and/or other pathogens. Consequently, the survivors used in set 5 were likely to be genetically more resistant than the naïve oysters used in set 4 , as demonstrated for the summer mortality phenomenon in C. gigas [33]. Another hypothesis could be related to the reproductive status. Sets 4 and 5 of trial 3 occurred in May and November of 2014, which represented the pre- and postspawning periods, respectively. Previous experiments have shown that the active gametogenesis period corresponds to higher susceptibility to vibriosis in mollusks [34-37]. Consequently, primary infection of C. gigas with $V$. aestuarianus by cohabitation showed a different mortality pattern according to the stage of development and the level of selection. Hence, evaluation of vibriosis resistance in C. gigas represents a complex interaction between the genotype and the stage of development, and therefore the size, reproductive status and age of 
the oysters as described for OsHV-1 in C. gigas [21, 33, 38]. Our study also revealed that selecting for resistance to OsHV-1 infection in spat did not confer either higher resistance or susceptibility to $V$. aestuarianus infection in adults, which was in agreement with similar studies in oyster species [39-41]. Experimental studies working on $V$. aestuarianus should replicate the oyster genotypes. The difference in mortality between the four lines used in our study also suggested a genetic basis for $V$. aestuarianus resistance in C. gigas, but this speculation required further investigation.

Our results showed high variability in the expression of selected immune-related genes that was dependent on the animal batch and age. This variability allowed the discrimination of oyster batches and correlated with their sensitivity to bacterial infection. Interestingly, expression of this set of immune-related genes was correlated with sensitivity to vibriosis rather than the genetic background. Because sensitivity to infection evolved depending on the oyster stage tested, the clustering of oyster batches also evolved in an age-dependent manner. At the juvenile stage, the lines selected for their resistance to OsHV-1 infection that presented low sensitivity to vibriosis were clearly discriminated from the control lines that presented higher sensitivity to $V$. aestuarianus infection. At the adult stage, selected line A and control line $B$ showed intermediate sensitivity to vibriosis and were discriminated from control line A and selected line B with higher sensitivity to $V$. aestuarianus infection. Our results showed for the first time the possibility of using gene expression analysis to discriminate between oyster lines according to the resistance/susceptibility at two different developmental stages independent of the genetic background of the oyster lines. Specifically, four genes discriminated between the oyster lines according to their resistance/susceptibility.

These four genes are associated with different immune functions and suggest a complex discrimination of oyster lines through their immune status. The four genes able to discriminate oyster lines are related to antimicrobial functions (the proline rich peptide Cg-prp [42]), anti-oxidative responses (the extracellular superoxide dismutase $C g$-SOD [43]), cell adhesion (the Integrin beta-PS [44]) and recognition molecules (the L-rhamnose-binding lectin [45]). These results show that it is now necessary to develop global transcriptomic approaches to clearly elucidate the transcriptomic basis of the resistance/susceptibility of oysters.

Finally, trial 4 was designed to test the effect of successive challenges using survivors of a previous challenge. The survivors of an initial exposure to $V$. aestuarianus still exhibited significant mortality in response to the same pathogenic agent at the second exposure. Consequently, the survivors were not genetically resistant, but they were either less susceptible during the previous exposures or the infection cohabitation did not allow equal expose of the oysters to the bacteria. Thus, a first contact with $V$. aestuarianus is not protective. This mortality pattern was also found in the abalone Haliotis tuberculata during two successive infections by the pathogen Vibrio harveyi [46]. Our result contrasted with the results obtained for the summer mortality phenomenon and OsHV-1, for which the survivors were selected for resistance and exhibited low mortality the following year [33, 38]. Between trials 3 and 4, mortality due to $V$. aestuarianus was mostly observed after a spawning event, thereby reinforcing the importance of the reproductive status on the resistance to the bacteria. Post-spawning oysters were much more susceptible to the disease, as demonstrated with the mortality event due to opportunistic Vibrio sp in C. gigas [34, 37, 47] and OsHV-1 in C. gigas that occurred a couple of days after spawning [48]. Otherwise, the cumulative mortality after three successive exposures to $V$. aestuarianus was very high for all lines (ranging from 84 to $100 \%$ ) (Table 6). These mortality rates are extremely concerning for French oyster farmers, who cannot continue to remain feasible with this level of loss of $C$. gigas in their oyster stocks.

In conclusion, our study showed that: (1) cohabitation between injected oysters and healthy oysters seemed to be preferable for the genetic evaluation of $V$. aestuarianus resistance in $C$. gigas compared to intramuscular injection; (2) the mortality pattern for primary exposure to $V$. aestuarianus at the juvenile stage was similar to the pattern observed for OsHV-1 infection, with a higher resistance in selected oysters than control oysters, which suggested dual resistance at the juvenile stage; (3) differences in the mortality patterns were highlighted between juveniles and adults during primary infection, suggesting a complex interaction between the genotype and the stage of development for Vibrio sensitivity; and (4) selection of immune-related genes allowed for the discrimination of batches depending on their sensitivity to infection at the two stages tested rather than on their genotype. The differences in mortality among the lines also suggested a genetic basis for the resistance to $V$. aestuarianus infection. Similarly, selection to enhance OsHV-1 resistance did not confer increased susceptibility or resistance to $V$. aestuarianus infection. Therefore, to improve resistance to $V$. aestuarianus infection, a breeding program needs to use high intensities of selective pressure. Resistance to $V$. aestuarianus infection should be evaluated through successive exposures to the disease because the oysters remained susceptible to $V$. aestuarianus even if they survived one or several mortality outbreaks related to the disease. Breeding companies 
interested in enhancing Vibrio resistance should use oysters that were previously selected for resistance to OsHV-1 infection at the spat stage for broodstock. Then, these broodstocks should be evaluated at the adult stage to combine the resistance traits.

\section{Competing interests}

The authors declare that they have no competing interests.

\section{Author details}

1 Ifremer, Laboratoire de Génétique et Pathologie des Mollusques Marins, Avenue Mus de Loup, 17390 La Tremblade, France. ${ }^{2}$ Ifremer, IHPE, UMR 5244, Univ. Perpignan Via Domitia, CNRS, Univ. Montpellier, 34095 Montpellier, France.

\section{Authors' contributions}

Conceived and designed the experiments: PA, MAT and LD. Performed the experiments: PA, DT, MAT, JDL and LD. Analyzed the data: PA, JDL and LD. Wrote the manuscript: PA, MAT, JLD and LD. All authors read and approved the final manuscript.

\section{Acknowledgements}

We greatly thank Tristan Renault and Pierre Boudry for their support for the initial aim of this study. We thank the hatchery, nursery and genetic teams of the Laboratory of Genetics and Pathology of Marine Molluscs, Ifremer La Tremblade and Ifremer Bouin, for their assistance in oyster production. We thank the pathology team for technical support for the challenges in laboratory conditions. We gratefully acknowledge Agnès Vergnes for her technical support for the gene expression analyses and Aurélien Brun for his contribution to labeling the oysters. This study was supported by Ifremer through the research activity called "Amélioration par la sélection" and by the French Ministries of Ecology and Agriculture through the research activity called "AESTU".

Received: 31 July 2015 Accepted: 13 November 2015

Published online: 09 December 2015

\section{References}

1. Comps M, Duthoit J-L (1976) Infection virale associée à la "maladie des branchies" de l'huitre portuguaise Crassostrea angulata Lmk. CR Acad SC Paris Série D 283:1595-1597

2. Grizel H (1985) Etude des récentes épizooties de l'huitre plate (Ostrea edulis Linné) et leur impact sur l'ostréiculture bretonne. Université des Sciences et Techniques du Languedoc, Montpellier, p 145

3. Grizel H, Héral M (1991) Introduction into France of the Japanese oyster (Crassostrea gigas). I C E S J Mar Sci 47:399-403

4. Murray AG, Marcos-Lopez M, Collet B, Munro LA (2012) A review of the risk posed to Scottish mollusc aquaculture from Bonamia, Marteilia and oyster herpesvirus. Aquaculture 370:7-13

5. Martenot C, Fourour S, Oden E, Jouaux A, Travaille E, Malas JP, Houssin M (2012) Detection of the OsHV-1 mu Var in the Pacific oyster Crassostrea gigas before 2008 in France and description of two new microvariants of the Ostreid Herpesvirus 1 (OsHV-1). Aquaculture 338:293-296

6. Ségarra A, Pépin JF, Arzul I, Morga B, Faury N, Renault T (2010) Detection and description of a particular Ostreid herpesvirus 1 genotype associated with massive mortality outbreaks of Pacific oysters, Crassostrea gigas, in France in 2008. Virus Res 153:92-99

7. Francois C, Joly J-P, Garcia C, Lupo C, Travers M-A, Pépin J-F, Hatt P-J, Arzul I, Omnes E, Tourbiez D, Faury N, Haffner P, Huchet E, Dubreuil C, Chollet B, Renault T, Cordier R, Hébert P, Le Gagneur E, Parrad S, Gerla D, Annezo J-P, Terre-Terrillon A, Le Gal D, Langlade A, Bedier E, Hittier B, Grizon J, Chabirand J-M, Robert S, Seugnet J-L, Rumebe M, Le Gall P, Bouchoucha M, Baldi Y, Masson J-C (2013) Bilan 2012 du réseau REPAMO_Réseau national de surveillance de la santé des mollusques marins

8. Francois C, Joly J-P, Garcia C, Lupo C, Travers M-A, Tourbiez D, Chollet B, Faury N, Haffner P, Dubreuil C, Serpin D, Renault T, Cordier R, Hébert P, Le Gagneur E, Parrad S, Gerla D, Cheve J, Penot J, Le Gal D, Lebrun L, Le Gac-Abernot C, Langlade A, Bédier E, Palvadeau H, Grizon J, Chabirand
J-M, Robert S, Seugnet J-L, Rumebe M, Le Gall P, Bouchoucha M, Baldi Y, Masson J-C (2014) Bilan 2013 du réseau REPAMO—Réseau national de surveillance de la santé des mollusques marins

9. Francois C (2015) Bilan 2014 du réseau REPAMO_Réseau national de surveillance de la santé des mollusques marins

10. Pépin J-F, Soletchnik P, Robert S (2014) Mortalités massives de l'Huître creuse. Synthèse-Rapport final des études menées sur les mortalités de naissains d'huitres creuses $C$. gigas sur le littoral charentais pour la période de 2007 à 2012

11. Dégremont L, Nourry M, Maurouard E (2015) Mass selection for survival and resistance to OsHV-1 infection in Crassostrea gigas spat in field conditions: response to selection after four generations. Aquaculture 446:111-121

12. Dégremont $L$ (2011) Evidence of herpesvirus (OsHV-1) resistance in juvenile Crassostrea gigas selected for high resistance to the summer mortality phenomenon. Aquaculture 317:94-98

13. Dégremont L, Bédier E, Boudry P (2010) Summer mortality of hatcheryproduced Pacific oyster spat (Crassostrea gigas). II. Response to selection for survival and its influence on growth and yield. Aquaculture 299:21-29

14. Dégremont L, Soletchnik P, Boudry P (2010) Summer mortality of selected juvenile Pacific oyster Crassostrea gigas under laboratory conditions and in comparison with field performance. J Shellfish Res 29:847-856

15. Dégremont L, Lamy J-B, Pépin J-F, Travers M-A, Renault T (2015) New insight for the genetic evaluation of resistance to ostreid herpesvirus infection, a worldwide disease, in Crassostrea gigas. PLoS One 10:e0127917

16. de Lorgeril J, Zenagui R, Rosa RD, Piquemal D, Bachère E (2011) Whole transcriptome profiling of successful immune response to Vibrio infections in the oyster Crassostrea gigas by digital gene expression analysis. PLoS One 6:e23142

17. Rosa RD, de Lorgeril J, Tailliez P, Bruno R, Piquemal D, Bachère E (2012) A hemocyte gene expression signature correlated with predictive capacity of oysters to survive Vibrio infections. BMC Genomics 13:252

18. Schmitt P, Santini A, Vergnes A, Dégremont L, de Lorgeril J (2013) Sequence polymorphism and expression variability of Crassostrea gigas immune related genes discriminate two oyster lines contrasted in term of resistance to summer mortalities. PLoS One 8:e75900

19. Zhang L, Li L, Zhang G (2011) A Crassostrea gigas Toll-like receptor and comparative analysis of TLR pathway in invertebrates. Fish Shellfish Immunol 30:653-660

20. Rosa RD, Santini A, Fievet J, Bulet P, Destoumieux-Garzon D, Bachère E (2011) Big defensins, a diverse family of antimicrobial peptides that follows different patterns of expression in hemocytes of the oyster Crassostrea gigas. PLoS One 6:e25594

21. Dégremont $L$ (2013) Size and genotype affect resistance to mortality caused by OsHV-1 in Crassostrea gigas. Aquaculture 416:129-134

22. Schikorski D, Renault T, Saulnier D, Faury N, Moreau P, Pépin JF (2011) Experimental infection of Pacific oyster Crassostrea gigas spat by ostreid herpesvirus 1: demonstration of oyster spat susceptibility. Vet Res 42:27

23. Saulnier D, De Decker S, Haffner P, Cobret L, Robert M, Garcia C (2010) A large-scale epidemiological study to identify bacteria pathogenic to Pacific oyster Crassostrea gigas and correlation between virulence and metalloprotease-like activity. Microbial Ecol 59:787-798

24. Schikorski D, Faury N, Pépin JF, Saulnier D, Tourbiez D, Renault T (2011) Experimental ostreid herpesvirus 1 infection of the Pacific oyster Crassostrea gigas: kinetics of virus DNA detection by q-PCR in seawater and in oyster samples. Virus Res 155:28-34

25. De Decker S, Saulnier D (2011) Vibriosis induced by experimental cohabitation in Crassostrea gigas: evidence of early infection and downexpression of immune-related genes. Fish Shellfish Immunol 30:691-699

26. Webb SC, Fidler A, Renault T (2007) Primers for PCR-based detection of Ostreid herpes virus-1 (OsHV-1): application in a survey of New Zealand molluscs. Aquaculture 272:126-139

27. Saulnier D, De Decker S, Haffner P (2009) Real-time PCR assay for rapid detection and quantification of Vibrio aestuarianus in oyster and seawater: a useful tool for epidemiologic studies. J Microbiol Methods 77:191-197

28. Pfaff MW (2001) A new mathematical model for relative quantification in real-time RT-PCR. Nucleic Acids Res 29:e45 
29. Garcia C, Thébault A, Dégremont L, Arzul I, Miossec L, Robert M, Chollet B, Francois C, Joly J-P, Ferrand S, Kerdudou N, Renault T (2011) Ostreid herpesvirus 1 detection and relationship with Crassostrea gigas spat mortality in France between 1998 and 2006. Vet Res 42:73

30. Goudenège $D$, Travers M-A, Lemire A, Petton $B$, Haffner $P$, Labreuche $Y$, Tourbiez D, Mangenot S, Calteau A, Mazel D, Nicolas J-L, Jacq A, Le Roux F. A single regulatory gene is sufficient to alter Vibrio aestuarianus pathogenicity in oysters. Environ Microbiol (in press)

31. Ragone Calvo LMR, Calvo GW, Burreson EM (2003) Dual disease resistance in a selectively bred Eastern oyster, Crassostrea virginica, strain tested in Chesapeake Bay. Aquaculture 220:69-87

32. Dégremont L, Garcia C, Allen SK Jr (2015) Genetic improvement for disease resistance in oysters: a review. J Invertebr Pathol 131:226-241

33. Dégremont L, Boudry P, Ropert M, Samain JF, Bédier E, Soletchnik P (2010) Effects of age and environment on survival of summer mortality by two selected groups of the Pacific oyster Crassostrea gigas. Aquaculture 299:44-50

34. De Decker S, Normand J, Saulnier D, Pernet F, Castagnet S, Boudry P (2011) Responses of diploid and triploid Pacific oysters Crassostrea gigas to Vibrio infection in relation to their reproductive status. J Invertebr Pathol 106:179-191

35. Travers M-A, Le Goïc N, Huchette S, Koken M, Paillard C (2008) Summer immune depression associated with increased susceptibility of the European abalone, Haliotis tuberculata to Vibrio harveyi infection. Fish Shellfish Immunol 25:800-808

36. Travers MA, Basuyaux O, Le Goic N, Huchette S, Nicolas JL, Koken M, Paillard C (2009) Influence of temperature and spawning effort on Haliotis tuberculata mortalities caused by Vibrio harveyi: an example of emerging vibriosis linked to global warming. Glob Change Biol 15:1365-1376

37. Wendling CC, Wegner KM (2013) Relative contribution of reproductive investment, thermal stress and Vibrio infection to summer mortality phenomena in Pacific oysters. Aquaculture 412:88-96

38. Pernet F, Barret J, Le Gall P, Corporeau C, Dégremont L, Lagarde F, Pépin JF, Keck N (2012) Mass mortalities of Pacific oysters Crassostrea gigas reflect infectious diseases and vary with farming practices in the Mediterranean Thau lagoon, France. Aquac Environ Interact 2:215-237
39. Burreson EM (1991) Susceptibility of MSX-resistant strains of the eastern oyster, Crassostrea virginica, to Perkinsus marinus. J Shellfish Res 10:305-306

40. Dove MC, Nell JA, O'Connor WA (2013) Evaluation of the progeny of the fourth-generation Sydney rock oyster Saccostrea glomerata (Gould, 1850) breeding lines for resistance to QX disease (Marteilia sydneyi) and winter mortality (Bonamia roughleyi). Aquac Res 44:1791-1800

41. Frank-Lawale A, Allen SK, Dégremont L (2014) Breeding and domestication of eastern oyster (Crassostrea Virginica) lines for culture in the midatlantic, USA: line development and mass selection for disease resistance. J Shellfish Res 33:153-165

42. Guéguen Y, Romestand B, Fievet J, Schmitt P, Destoumieux-Garzon D, Vandenbulcke F, Bulet P, Bachère E (2009) Oyster hemocytes express a proline-rich peptide displaying synergistic antimicrobial activity with a defensin. Mol Immunol 46:516-522

43. Gonzalez M, Romestand B, Fievet J, Huvet A, Lebart M-C, Guéguen Y, Bachère $E$ (2005) Evidence in oyster of a plasma extracellular superoxide dismutase which binds LPS. Biochem Biophys Res Commun 338:1089-1097

44. Jia Z, Zhang T, Jiang S, Wang M, Cheng Q, Sun M, Wang L, Song L (2015) An integrin from oyster Crassostrea gigas mediates the phagocytosis toward Vibrio splendidus through LPS binding activity. Dev Comp Immunol 53:253-264

45. Roberts S, Goetz G, White S, Goetz F (2009) Analysis of genes isolated from plated hemocytes of the Pacific oyster, Crassostreas gigas. Mar Biotechnol 11:24-44

46. Travers MA, Meistertzheim AL, Cardinaud M, Friedman CS, Huchette S, Moraga D, Paillard C (2010) Gene expression patterns of abalone, Haliotis tuberculata, during successive infections by the pathogen Vibrio harveyi. J Invertebr Pathol 105:289-297

47. Li Y, Qin JG, Li XX, Benkendorff K (2009) Spawning-dependent stress responses in pacific oysters Crassostrea gigas: a simulated bacterial challenge in oysters. Aquaculture 293:164-171

48. Dégremont L, Guyader T, Tourbiez D, Pépin J-F (2013) Is horizontal transmission of the Ostreid herpesvirus OsHV-1 in Crassostrea gigas affected by unselected or selected survival status in adults to juveniles? Aquaculture 408:51-57

\section{Submit your next manuscript to BioMed Central and we will help you at every step:}

- We accept pre-submission inquiries

- Our selector tool helps you to find the most relevant journal

- We provide round the clock customer support

- Convenient online submission

- Thorough peer review

- Inclusion in PubMed and all major indexing services

- Maximum visibility for your research

Submit your manuscript at www.biomedcentral.com/submit

\section{() Biomed Central}

